\title{
ALIGNING CORPORATE SOCIAL RESPONSIBILITY WITH THE UNITED NATIONS' SUSTAINABILITY GOALS: TRICKIER THAN IT SEEMS?
}

\section{A STUDY OF SOCIAL ENTREPRENEURSHIP IN SWEDEN}

\author{
Christer Thörnqvist ${ }^{1}$, Jonna Kilstam ${ }^{2}$
}

date of paper receipt:

12.10.2020.

Original Article date of sending to review:

14.10.2020.

doi: 10.2478/eoik-2021-0009 date of review receipt:

20.04.2021.

UDK 005.35/.5:321.6/.8(485)

1,2Skövde Business School, Skövde University, Sweden, e-mail: christer.thornqvist@his.se, jonna.kilstam@his.se

\section{ABSTRACT}

This article explores the profound mismatch between the United Nations 2030 Agenda for Sustainable Development and fundamentals for Corporate Social Responsibility (CSR). The common survival of human life, society, and the global order as we know it, and the need for companies to make profit is not easy. The intractability of the problem is often underestimated in public as well as scientific debate. This article discusses the problem and possible ways to cope with it through 'social entrepreneurship' illustrated here by a study of nine firms in Sweden. The study draws on an amalgamation of Schumpeterian theory about "creative destruction" and the concept of "Emerging Davids vs. Greening Goliaths."

\section{Keywords:}

Social entrepreneurship; 2030 Agenda for Sustainable Development; Archie Carroll's CSR pyramid; Emerging Davids vs. Greening Goliaths. 


\section{INTRODUCTION}

In 2015, the United Nations (UN) adopted its “2030 Agenda for Sustainable Development”, whose 17 overarching goals would together reduce extreme inequality, improve health and education, spur growth, preserve the environment, and tackle climate change. The Agenda did not arise from nothing; already in 1987, Our Common Future, the UN's Brundtland Commission report, stated that sustainability rests on three pillars: an ecologic, an economic and a social one (WCED, 1987). Those same three pillars are also essential to conventional understandings of Corporate Social Responsibility (CSR), which places critical responsibility on the private sector for protecting future generations from environmental and related social and economic disaster.

The amalgamation of the UN's goals and the CSR pillars are more difficult than it seems at a first glance. It is not just a matter of resistance to big corporations' investments in fossil energy and other industrial inputs. It is a more fundamental question of how to align the survival of the environment and the economy, problems that are often underestimated in public as well as scholarly debate. This article discusses the fundamental contradiction between environment and economy, but it also highlights a possible contribution to the solution of the problem.

The UN Agenda calls for achieving its goals by 2030 at the latest. The most burning issue is the ecologic one. Because of the global climate crisis, we are on our way toward several environmental tipping points when the destruction of the climate fuels itself. Global heating continues no matter what humans do to reverse it.

The 17 UN goals are illustrated in the following way:

Figure 1. The three levels of sustainability

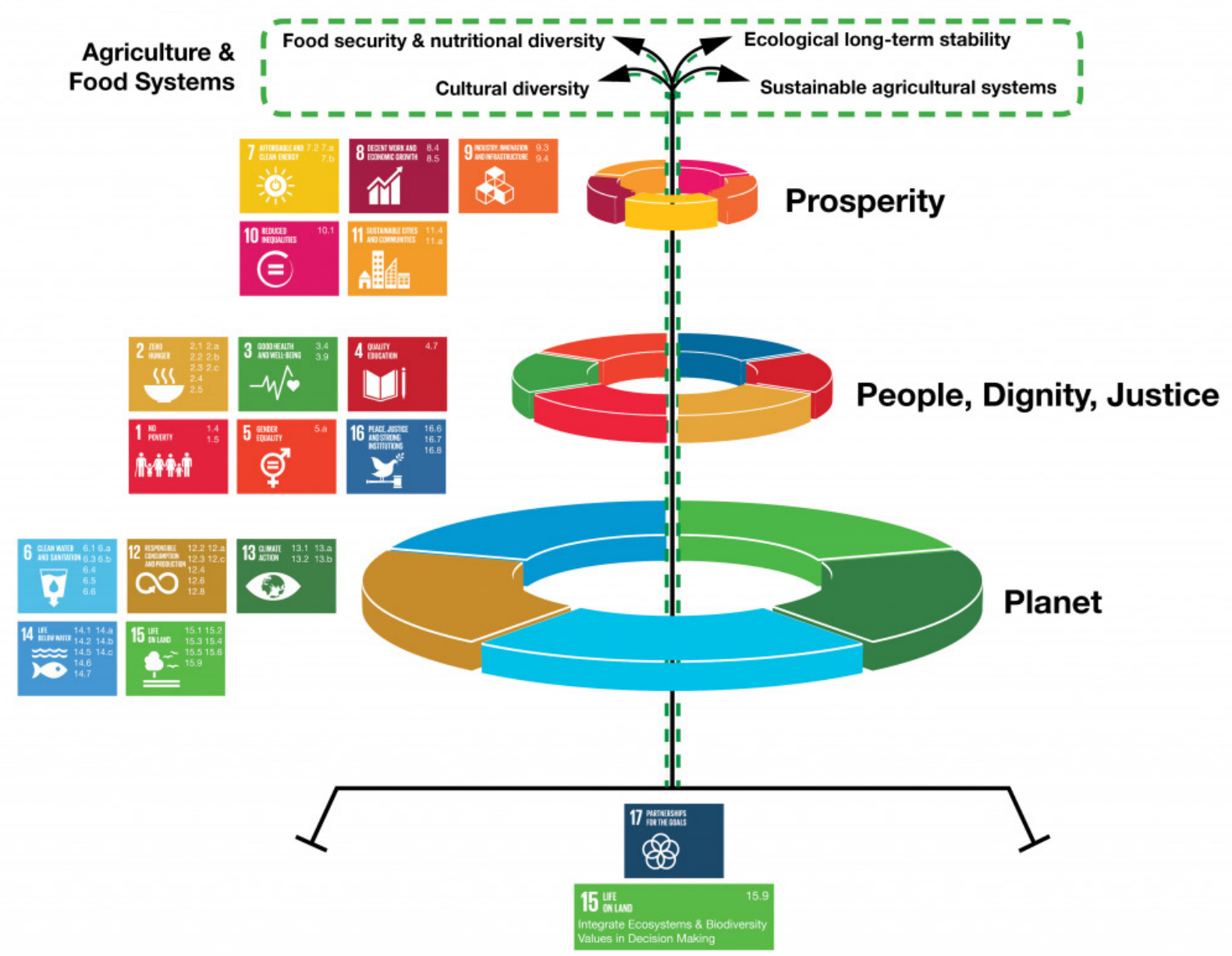

Source: United Nations: UNSSC Knowledge Centre for Sustainable Development, 2016 
In turn, the three pillars derived from the above-mentioned Brundtland Commission's report Our Common Future defined a sustainable development in the following way:

A development that meets the needs of the present without compromising the ability of future generations to meet their own needs (WCED, 1987, p. 35).

According to Mitcham (1995), Our Common Future was a compromise between environmental activists who stressed the need to limit economic growth in order to meet the climate challenges and economic interests calling for growth on the grounds, in part, to ease poverty in developing countries. Our Common Future held that contradictory demands could be reconciled; economic development was possible even under sustainability constraints. For example, conditions in the 'Global South' have improved in many ways over the last half century, in particular regarding health (Rosling, 2018). Yet the idea of economic growth as a precondition for environmental and social development has become more and more problematic due to the long-term finiteness of global resources. What was new with the Brundtland Commission report was that it juxtaposed three forms of sustainability as equal in long-run importance: economic, environmental and social sustainability (Purvis et al., 2019).

But as figure 1 shows, the UN does no longer see the three pillars as equal. The three layers of the cone states that environmental sustainability is more fundamental than the other two, and social sustainability (people, dignity, justice) is in turn more crucial than economic sustainability. This global perspective is not surprising given how the climate crisis has become more threathening since the 1987 publication of Our Common Future.

\section{WHAT IS THE PUZZLE?}

The United Nations consists of member states, not member companies. Hence it is only natural that the responsibility for the adaptation to the UN-17 goals lies on the country level, although it is sometimes stressed that nation states, big corporations and individual consumers alike are responsible for the environment. On the one hand, overarching cooperation of several actors under the umbrella of the UN goals is fundamental. On the other though, there is a risk that no single actor can be held responsible for the lack of success in meeting the goals. For instance, parliaments are limited by voters' mistrust in regulations and might therefore hand over the responsibility for a more sustainable consumption to voters themselves; as long as the voters are aware of the impact they make on the environment, they are supposed, even 'obliged' to make good decisions (Lorek and Spangenberg, 2014). Another aspect of the issue is that consumers find it difficult to cope with new views of consumerism. The new views might rather lead to a 'lock-in' of consumer behaviour resulting from anxiety about the new expectations they are exposed to. In other words, consumers tend to maintain an unsustainable behavior even when they have a general understanding of and positive attitude about green consumption (Jackson 2011; Nguyen et al. 2019). Hence new values and better information is not enough to achieve sustainable consumption; producers and merchandisers are responsible for increasing the supply of sustainable goods (Banerjee 2003; Nguyen et al. 2019).

Banerjee (2003) claims that many companies' understanding of sustainability is rather to achieve sustainable firms, not a sustainable planet. Although there is a need for a profound rethinking of business models if production and consumption shall be in concordance with the limitations posed by the global ecosystem, this poses the question to what extent companies are able to achieve such a transformation without jeopardizing their economic sustainability. From a short-term perspective, their survival as firms depend on the ability to compete with other companies, a competition made 
even more problematic as consumers' positive attitudes towards green consumption is not mirrored in their actual purchasing decisions (Nguyen et al., 2019).

When it comes to sustainable firms, one name sticks out, namely Archie Carroll. Carroll's ideas are familiar to researchers in the field, but his ideas might still need a description in order to clarify their role for our argument.

\section{CARROLL'S PYRAMID OF CORPORATE SOCIAL RESPONSIBILITY}

(All citations in this section are taken from Carroll (2016).)

In 1991, Archie Carroll famously developed a definition of the sustainable corporation, depicted below. Carroll choosed the geometric design of a pyramid because it was "simple, intuitive, and built to withstand the test of time." Hence, he placed economic responsibility at the base because it is a foundational requirement in business. Sustained profitability supports society's other expectations of corporations; the infrastructure of CSR must build upon the premise of an economically sound and sustainable business.

At the same time, society instructs corporations to obey the law and regulations because they are the "codification of the basic ground rules upon which business is to operate in a civil society." Turning to CSR in developing countries, whether a legal and regulatory framework exists or not affects whether multinationals choose to invest there or not because a legal infrastructure is crucial to provide a foundation for legitimate business growth.

Additionally, companies are supposed to operate ethically. That is, companies are expected to "do what is right, just, and fair and to avoid or minimize harm to all the stakeholders with whom it interacts." Finally, companies are expected to be good corporate citizens: "to give back and to contribute financial, physical, and human resources to the communities of which [they are] a part."

Figure 2. Carroll's pyramid

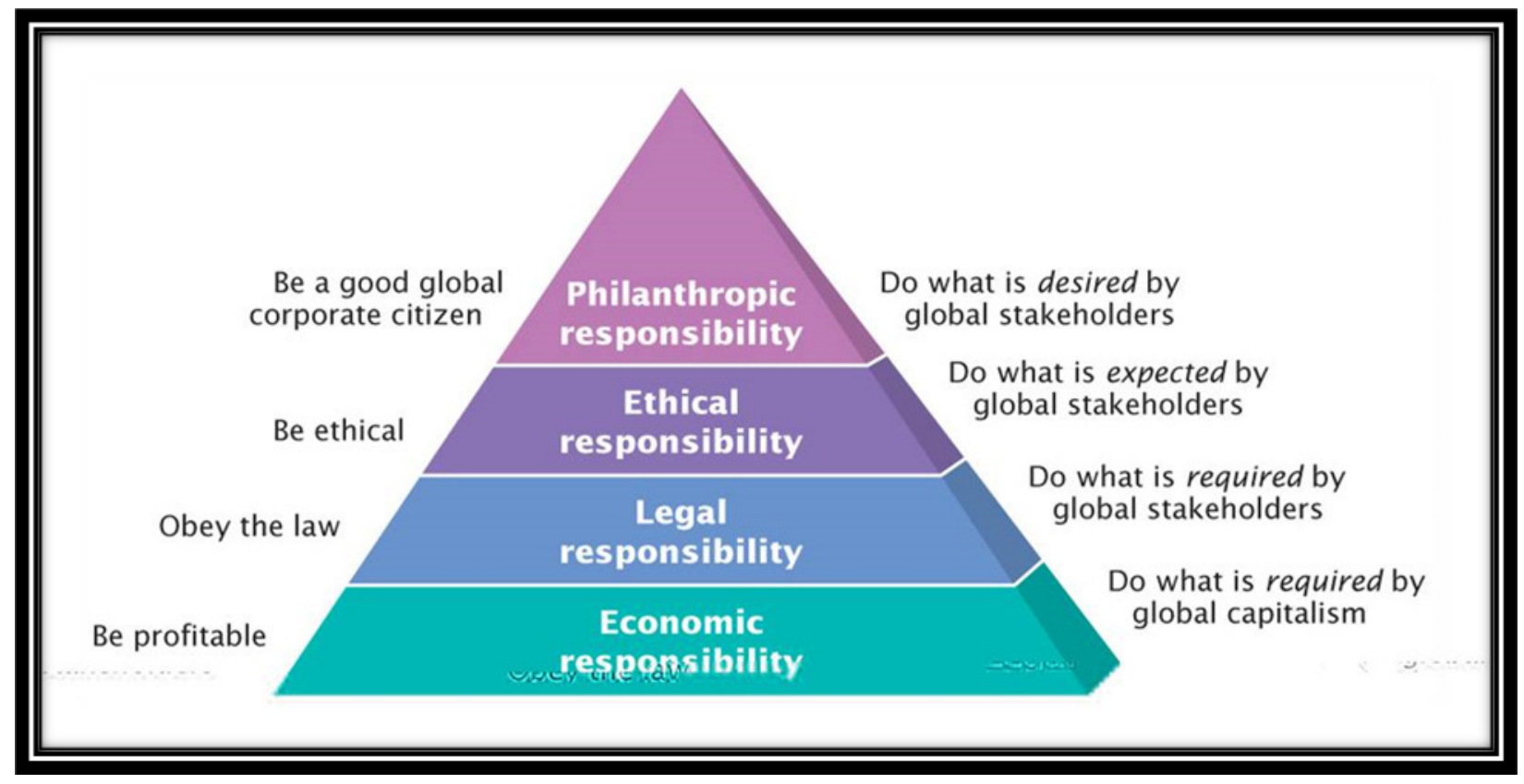

Source: Carroll (2016).

All four layers of the pyramid must be responsibly addressed to achieve CSR. Yet, according to 
Carroll, ethics 'permeates' the pyramid. Although ethical responsibility is a separate tier, ethical considerations should also figure in each of the other responsibility categories. Considering economic responsibility, for instance, the pyramid assumes a society where the quest for profits is a legitimate, fair expectation; a company must benefit from its investments. Regarding legal responsibility most laws and regulations are passed on the basis of appropriate, ethical reasoning. They address ethical issues such as "a concern for consumer safety, employee safety, the natural environment, etc." Moreover, ethical responsibility stands on its own as a category embracing policies and practices that entail higher level of expectation than the minimums required by law. To clarify, law can be seen as requiring 'passive compliance' while ethics might foresee future laws and thus strive to do what is considered above many laws, that which is driven by righteousness. Finally, philanthropic, or discretionary, responsibility is often ethically motivated by companies' drive "to do the right thing." Corporations sometimes pursue philanthropy as a utilitarian decision, for instance so-called strategic philanthropy just to be seen as good corporate citizens. Yet some firms also pursue philanthropy as "the virtuous thing to do." Philanthropy is then ethically motivated or altruistic in nature. To conclude, ethical motivations are fundamental for all four of the CSR layers and consequently carries a vital role in the totality of CSR.

\section{RETURNING TO THE PUZZLE: HOW DOES CARROLL'S PYRAMID ALIGN WITH THE UN?}

Archie Carroll's view of the socially responsible firm has had a great impact on the scholarly debate on sustainability. However, there are some obvious problems in its relations to connect it with the UN goals. One most tangible problem is that many multinationals care little for either ethics or the environment in general as long a they make profit. This is particularily true in the petroleum and coal industries. Big companies in fossil fuel have been aware of the connection between their products and global warming for at least half a century, but instead of doing something about the problem, they launched 'denial machines', i.e. think-tanks and institutes in order to create false research about the climate changes (Dunlap, 2013).

Another less obvious but fundamental obstacle can be seen if we juxtapose the UN's 17 goals and the CSR pyramid in figures 1 and 2. Strikingly, the pyramid looks like the UN cone upside-down. The most fundamental task of an individual company-to be profitable-is the least crucial in the global perspective and vice versa. This begs questions not put, or only vaguely addressed among politicians and scholars. How is it possible to involve even environmentally conscious corporations in the necessary global transformation to save the climate if the firms at the same time risk the fundamentals for their own existence?

The second half of this article discusses the kind of companies that might in the longer run be important players for bridging this gap, namely 'social entrepreneurs'. Our empirical evidence draws from a study on nine such firms in Sweden in early spring 2020 - just before the coronavirus pandemic. Although small today, these companies might have the potential to make a serious impact as we will see below, if following the old principle "think globally, act locally."

\section{WHAT IS SOCIAL ENTREPRENEURSHIP?}

A basic difference between CSR and social entrepreneurship is that the social entrepreneur has created the firm with the primary aim of solving a societal problem while still making a profit; the social entrepreneur prioritises the social effects of the business. Another difference is seen in measures of performance. A traditional entrepreneur uses indicators such as market shares and 
customer satisfaction, but it is trickier for the social entrepreneur (Austin et al. 2006). Before measuring efficiency and societal impact one must first decide which initiatives and measures make the best contribution to society and its future (Dees 2007). Another difference is the realm of possibilities. While the traditional entrepreneur sees possibilities in creating new products for previously unknown needs, the social entrepreneur seeks a solution to long-term, more basic needs (Austin et al., 2006). Unlike traditional entrepreneurs who are depending on profit in order to survive, social entrepreneurs work in non-profit organizations, in for-profit organizations, and in a mix of the two (Dees, 2007). Austin et al. (2006) therefore emphasizes that an 'entrepreneur' should not be viewed as either traditional or societal but rather as somewhere on a continuum between the two poles of purely social to purely economic.

So, in which ways are social entrepreneurs useful? The societal entrepreneur carries a role as an agent of change (Dees 1998; Partzsch and Ziegler 2011). Johannisson and Wigren (2009) compares the social entrepreneur to the beloved children's book character Pippi Longstocking, a provocateur who refuses to be a conformist and uses her quirky abilities to challenge the norm. Dees (2007) argues that social entrepreneurship has greater potential for transformation than governmental initiatives owing to the lack of bureaucracy. The forwarding of societal sustainability in particular and development in general has been found to depend on innovations despite the accompanying high degree of uncertainty. The social entrepreneurs' independence from governments and freedom to develop new environment-friendly goods and services, sometimes introduced to new markets, proved favourable (Dees, 2007).

The ideal of social entrepreneurship carries several close points of similarity with Josef Schumpeter's (2003 [1942]) idea of 'creative destruction.' New customers, merchandize, market and organizations, triggers the destruction of old economic structures in favour of new ones. Rahdari et al. (2016) prefer the concept 'creative construction' when it comes to social entrepreneurship since it is a means to go beyond the satisfaction of obvious needs.

\section{EMERGING DAVIDS VS. GREENING GOLIATHS}

Big companies have the greatest power to impact norms and structures regarding sustainability issues. Yet, as Rahdari et al. (2016) point out, societal change sometimes starts with passionate individuals and non-profit organizations that in turn affect decision-making at higher societal levels. Hockerts and Wüstenhagen (2010) highlights new initiatives by social entrepreneurs as Emerging Davids as triggers for Greening Goliaths, that is, big companies react on the new initiatives by incorporating sustainability issues. The latter tend to have a less ambigious relationship with its sustainability targets - yet on the other hand a better possibility to reach out due to their established market position and company size. Hockerts and Wüstenhagen further argue that established companies are trapped in a line of thought that 'business as usual' is not just working, but also the best, which makes innovative views on sustainability less likely. This is particularily true if a 'sustainable' innovation or product might compete with the firm's already existing line of production.

Schumpeter (1983 [1934], p. 86) emphasized the difficulty to step outside the limits set by routines: "Thought turns again and again into the accustomed track even if it has become unsuitable and the more suitable innovation in itself presents no particular difficulties. The very nature of fixed habits of thinking, their energy-saving function, is founded upon the fact that they have become subconscious."

Bornstein and Davis (2010) argue that social entrepreneurship is 'contageous', that is, a social entrepreneur following social goals might shed courage to others to follow suit. The field of social entrepreneurship thus tends to spontaneously stimulate the development of the field while it 
expands. No matter if the initiatives are small, the authors argue, they are strengthening each other and the sum of their impact might be considerable.

If we return to Hockerts and Wüstenhagen (2010), they claim that inspired Greening Goliaths through their size might take the sustainability initiative to industry-wide levels. Emerging Davids have their own challenges to handle because of limited resources and difficulties to reach beyond a small, environmentally or socially interested group of customers, accordingly lesser opportunities to directly affect the market in general. They thus argue for a closer cooperation between the small companies with big ideas, and the big companies with big market impact, but sometimes no creative ideas about sustainability at all.

Hockerts och Wüstenhagen (2010) further refer to the interplay between Emerging Davids and Greening Goliaths as a coevolution. This coevolution is supposed to start when a new societal entrepreneur launches a sustainability innovation in the market. As the societal entrepreneur is more prone to meet sustainability targets than immediate profits, the company does usually not grow so big that it will make any industry-level impact. But if the launched products or services are good enough, they will be picked up by bigger companies that can include them in their ordinary supply. A most obvious example of this is the inclusion of environmentally-friendly produced food, first sold by small producers in special stores or at farm-sales, but now available at any convenience store or supermarket in Europe or North America. In turn, a spread of such innovations leads to increased demand and consequently possibilities for Emerging Davids to grow and develop their competitive power, once again with food as a most obvious example. A growing demand in tandem with the increasing competition from Emerging Davids will also bring pressure to bear on bigger companies to act sustainable (Hockerts and Wüstenhagen, 2010).

The supposed development can be illustrated in the following figure:

Figure 3. The coevolution between social entrepreneurs and established firms towards a sustainability transformation.

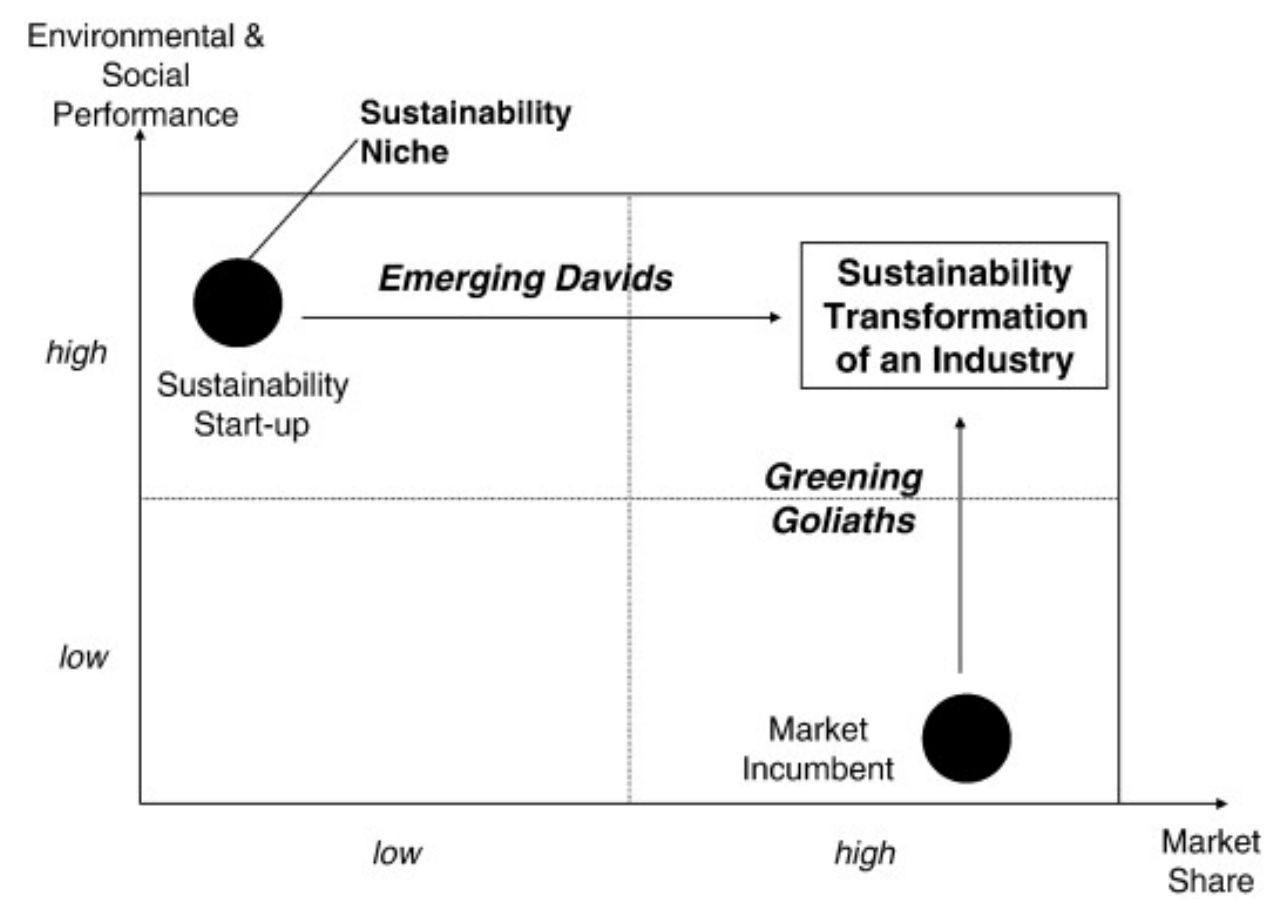

Source: Hockerts and Wüstenhagen, 2010 
At pace with an increasing market-share for sustainable goods and services we can assume that there is also a general transformation of consumer patterns. Yet, one disadvantage with the resulting price pressure might be, according to Hockers and Wüstenhagen (2010) that it likely lowers the sustainability impact as competition might in the longer run once again be based on price rather than quality. On the other hand, there is always room for Emergent Davids to initate new transformation cycles, starting at higher sustainability floors and thus taking the market to new sustainability levels. The ideal to make Goliaths become green is not far from the Shumpeterian idea of creative destruction; there is a need to rethink much of the previous structures of production. Schumpeter's (1942) understanding of creative destruction is that economic structures change partly because of small entrepreneurs' competitive power to set the table also for big corporations and compete with them. Actually, in the same year, in 1942 he reversed himself. Big firms have more incentive to invest in new products, he decided, because they can sell them to more people and reap greater rewards more quickly. Still, we stick to his original idea here. Moreover, Schumpeter could not foresee the debate about sustainability - he was dead long before that debate emerged - but his thinking is still interesting, although we do not have the space to go deeper into it in this article.

\section{OUR EMPIRICAL RESEARCH DESIGN}

The rest of this article is dedicated to a field study of social entrepreneurs in Sweden. The study was undertaken by Jonna Kilstam in spring 2020. It draws on semi-structured interviews, done over the phone because the global Covid-19 pandemic had hit Sweden by then. The interviews were all taped. They were between 30 and 90 minutes long, depending on the entrepreneur's wishes. The interviewees all received the questionnaire in advance. None of them wished to be anonymous; on the contrary, they welcomed the opportunity to get the name of their firms spread in social scientific literature.

Our sampling strategy was to find social entrepreneurs who were trying in some way to make retail consumption more sustainable-friendly. The sample covers a broad range of industries, and includes companies that try to promote 'new' consumption behaviour and firms that work with existing goods and use recycling or other means to limit waste. The social entrepreneurs were primarily found through a snowball sample via social media. Snowballing leads to some bias but since the alternative would have been fewer interviewees we believe that the pros outweight the cons.

In total, nine interviews were done. thereby meeting Grant McCracken's (1988) three general recommendations for the choice of interviewees in order to reach theoretical saturation:

- few in numbers - eight to ten interviewees is enough to achieve theoretical saturation, i.e. no new theoretically conflicting aspects will emerge beyond this number, given the selection criteria;

- strangers - the interviewees should not be acquainted with the researcher, thus maintaining an unbiased, scientific distance;

- not 'subjective' experts - the respondents should not be stakeholders or have other expertise beyond their own experiences.

It is also crucial that the interviewees share a similar horizon. They must have something that unifies them which in this case is guaranteed by the social entrepreneurship under Swedish legislation and a Swedish labour market regime. This is the smallest common denominator (McCracken, 1988; Thörnqvist and Bernhardsson, 2015). 
In addition, all the interviewees are founders or co-founders of firms whose primary mission is to promote sustainable consumption through social innovation. Five of the nine companies are exclusively from Stockholm while the other four are spread across the country: Nyköping (east), Luleå (north), Saxtorp (south) and Tibro (west). As mentioned, no company hesitated to appear under its real name; on the contrary, they appreciated the publicity. The people we interviewed are not merely entrepreneurs, they are passionate enthusiasts with souls of fire as you will see in the following brief descriptions.

Kadunk (onomatopoeic for the sound of a train's wheels against the rails) works to promote travels by train especially when going on holiday. Kadunk does this through events and lectures, and it also has a social platform where members share experiences from their train holidays.

Res eko (Travel Eco) is an independent web magazine devoted to sustainable tourism. The company aims to inspire people to travel and experience nature in a sustainable way, and it also champion a 'climate smart' way of life in general.

Food Fighters is a digital platform that figures out the most sustainable provisions in relationship to price. By simplifying sustainable choices and directing consumers toward sustainable and affordable groceries, their aim is to create consumer-driven demand for more sustainable items, thereby pressuring big grocery chains to commit to sustainability.

Enkla Kassen (the easy bag) delivers food (in bags) together with recipes that are based on a calculation of the environmental impact. The aim is to help consumers eliminate food waste and limit the consumption of animal products.

Hyber addresses waste generated byproducts for children; parents may exchange items thereby maximizing the length of time a product is used.

Rekokollen (Slang for 'the fairness check'; the closest we can get in English) is an Android application about skin care products aimed at customers and retailers. The target groups can discover whether or not an item contains industrially designed chemicals that are dangerous to the environment.

Goodlist is a platform where users can critique products on the basis of' their sustainability. The collated information can then be used to create informed consumers thereby steering companies in a more sustainable direction.

Bechange provides education and training aimed at helping customers to make "life style changes" thst is, lower their environmental footprint while still retaining their quality of life.

Sajkla (A cabinet-maker's term) is a service that refurbishes furniture and up-dates interior decor thereby encouraging consumers, individuals as well as organizations, to reuse items and materials rather than trashing them and replacing them with new items.

\section{WHAT THE INTERVIEWS REVEALED}

\section{The take-off}

The entrepreneurs had rather similar backgrounds in terms of education, work experience and previous involvement in sustainability related work. Some had engaged their whole working life to the latter issue, while others were newcomers in the field. Olivia Rothschild at Hyber is the 
only interviewee with an educational background in 'social entrepreneurship.' The great thing with social entrepreneurship, she claimed, is the combination of successful entrepreneurship in general and making a contribution to something bigger; solving societal problems which is not possible by, for instance, pure charity.

Daniel Gillan at Food Fighters told how he, during the last few years, had strived for ways to combine societal good with commercial business. His first project was unsuccessful, but instead of abandoning it he started a new firm that would make it possible to finance the failing project. The project became profitable, but it lacked the societal impact Daniel Gillan had expected. Hence he searched for a completely new business idea, which lead to Food Fighters. There Gillan achieved his double target: helping customers to save money when buying groceries while at the same time contributing to a more sustainable future.

Johannes Källgren at Enkla Kassen described the frustration he felt when working for a nongovernmental organization in the sustainability field. In particular, the strong competition between non-profit organizations for a limited amount of donor money triggered his frustration. It made him realise that donor-driven activities can never solve more than a small portion of the global challenges societies and the world economy are facing.

I wished to press for the kind of changes I saw in the non-profit organization I worked for, but at the same time I felt that social entrepreneurship would be a most suitable means to drive such a change; I would probably do more good for sustainability by starting companies than hunting donors; donations were never my 'core skill.'

Sajkla stands out from the other companies as it emerged from a project that had regional funding. The aim of the original project was to develop a closed-loop business model for furniture used by municipal officials and in administrative buildings. When Sajkla's present CEO, Jenny Ekman, got in touch with the project group it was stuck and faced the threat of disbanding. Ekman decided to try to save the project by changing the approach from a strategic one to a more operational one. Although it is only a village with some 11,000 inhabitants, Tibro, where Sajkla was founded, is one of the largest furniture producers in Sweden. In collaboration with some furniture manufacturers in Tibro the project narrowed its focus to refurbishing furniture that would otherwise be discarded. This worked and Sajkla began to sell its services. Ekman had in her own words always thought of herself as a social reformer with a local perspective. She was driven by the desire to promote ecological sustainability while at the same time reducing public spending: instead of buying new furniture, municipal and regional bodies should buy refurbished or second-hand and new furniture should be the last resort. Ekman proved that sustainable solutions can be competitive even in the heart of the new furniture market.

\section{Driving forces}

A not expected finding from our study was that all our interviewees got their idea for their social entrepreneurship from their experiences as customers; it was their interest in sustainable goods and services from a consumer's point of view that triggered their desire to innovate. An illuminating example is Carina Lagerstedt Nilsson at Rekokollen. After giving birth, she began to check the ingredients in skin-care products. Her research inspired her to create Rekokollen.

Erik Sörgren at Res Eko got his idea for a service promoting sustainable tourism on his way home from a far from sustainable Asian trip, and Susanna Elfors launched Kadunk after a disappointing holiday by train. Jonas Ingre at Goodlist told us that the service he designed was something he personally needed, and when that idea became rooted in his mind he felt more or less obliged to 
make it materialize.

Johannes Källgren at Enkla Kassen and Daniel Gillan at Food Fighters differ from the other interviewees in one respect. They were both driven to start their companies by a broad desire to contribute somehow to the solving of society's urgent sustainability problem, in some as yet unspecified manner. Gillan had recently had to drop another social entrepreneurship project, while Källgren had challenged himself to come up with 100 business ideas that could have a positive impact on some major global problem and be commercially viable. Out of 100 such ideas, Källgren believed one at least would be possible to execute. Enkla Kassen was \# 70 on the list! It emanated from Källgren's attempt to eat more sustainably; he saw the need for something that would facilitate the endeavor. Affordable, vegan food that was easy to cook.

Daniel Gillan at Food Fighters describes how he got his idea in a convenience store when he was chosing between non-domestic but ecological honey and locally produced but non-ecological honey and realised he lacked the knowledge to make a sound decision. Hence the idea to offer a service that could instantly provide consumers with information that matched their individual preferences.

In fact all our interviewees emphasized that one of their primary motivations was the desire to help individual customers make educated choices. Daniel Gillan at Food Fighters expressed the need for consumer support in the following way:

If we take it from my point of view, I usually say that I'm a lazy middle-aged man. I want to do the right thing, but I don't have the energy. /.../ We therefore decided that what people such as myself needed was an 'outsourcing partner' that makes sustainable choices for me, free of charge. That could get people like me, that is, the vast majority of people, to move in the right direction.

Olivia Rothschild at Hyber argued in a similar manner that simplicity is the secret that makes a business model work. In the case of Hyber, parents might very well embrace the concept of exchanging or renting things instead of buying them new, but this is seldom enough for the same parents to actually chose the first alternative. They need a trigger.

\section{How to find customers}

Several of the interviewees acknowledged price pressure as they tried to avoid pricing their goods and services so high that they become luxuries which regular people would seldom buy unless they had an extraordinary degree of commitment to sustainability. Other interviewees noted that their companies mainly attract consumers who have a strong interest in sustainability and actively search for products such as they offer. Susanna Elfors at Kadunk, for example, described how their digital platform targets people who are searching for information and inspiration about travelling in an environment-friendly way. Interest in their platform increased dramatically when they got exposure in national and international media. This pushed them over the threshold and they reached travellers other than the environmentally motivated ones.

Our interviewees found other means to reach beyond the already active environmentalists. For instance, Food Fighters ranks products and retailers not only by environmental and climate aspects, but by their health benefits. A consumer with little interest in sustainability would therefore find the service useful and this in turn could lead them to include of sustainability in their future choices. Furthermore, as Daniel Gillan has argued as interest grows in Food Fighter rankings, grocery producers and retailers are pressured to become more sustainable to raise their ranking. 
In the case of Enkla Kassen, a customer survey revealed that only 20 percent of the customers are vegan while 50 percent are not. This was interpreted by the company as a proof that it had reached beyond its originally intended target group, and that it thus pressed for a move toward more vegetable diets. Ann Murugan at Bechange put it in this way:

By 2027, 20 per cent of all Swedes will understand and live in 'climate smart' ways and also know how to cope with their feelings and thoughts regarding this climate crisis. If 20 percent of the people are aware of tipping points /.../ When that many, about 20 per cent of the population, are willing to do something, the wage-scale might tip so the majority will follow suit.

Through reaching out to a large portion of the population, the initial 20 percent who make life style changes Bechange hopes to reach even further and involve society at large in the search for a sustainable world.

Several of the companies present figures on their hompages that show the climate gain for each choice in comparison to a 'traditional' alternative. Some companies even present figures for the total savings in $\mathrm{CO}_{2}$ emissions when all customers' consumption is taken into account. In the words of Daniel Gillan at Food Fighters:

First and foremost we wish to give people the feeling that they belong to a community. A feeling I myself often get - and I believe I share that feeling with many people - is that my little drop in the ocean doesn't mean anything. Thus you have your own results so you can improve yourself, also a notion of how much we at Food Fighters have one together, a community!

Moreover, all the companies, not surprisingly, use digital and web-based solutions to increase their outreach and hence their performance. Ann Murugan at Bechange explained how classroom activities linked to mobile applications, thereby reaching more consumers who potentially will live a climate-friendly life. Increased traffic also makes the service accessible at a lower price, leading to a greater spread geographically and socio-economically.

\section{How to impact other producers}

All the interviewees shared a wish to impact the privately owned businesses in their area. By inspiring, pressurising, and facilitating these private actors their aim is to make private business take greater responsibility for sustainability. Rekokollen does this by providing information about which products should be included or excluded in a sustainable supply. Food Fighters's platform was not yet launched when this is written due to the Covid-19 crisis, but according to the founders it has already made an impact on several of the big food market chains in Sweden. In Food Fighters's own words, it has triggered a reaction among even the big actors in the Swedish food market; they now compete over being in the forefront of sustainable grocery supplies. Johannes Källgren, of Enkla Kassen, also had a positive view on their competition with the 'old' firms:

We kind of see all solutions driving toward a more plant-based, climate-friendly nutrition as great. It is more like we run a joint business rather than compete with each other.

Källgren describes it as a wish to be a catalyst, helping other companies contributing to something good. Susanna Elfors from Kadunk, takes this a step further by giving talks to the aviation industry - an industry she claimed Kadunk is in strong opposition to! Elfors noted that the positive reaction of the big players in aviation are due to the upswing for train-travel holidays, and greenwashing rather than serious attempts to improve the sustainability of the industy or sector. More small actors, she argues, are necessary to persuade the big players to take a more sustainable approach. 
She has had a political impact, which was not a bad start:

The Swedish Minister of Infrastructure, Tomas Eneroth, refers to us when he pushes for night trains [instead of flights]; that's kind of a 'game changer.'

Daniel Gillan of Food Fighters stressed the notion that a community comprised of customers would impact the grocery industry at large. That might in turn bring pressure to bear on the producers who do not reach the sustainability target.

Jenny Ekman described how Sajkla's activities have encouraged the producers they work with to speak of sustainability with new confidence. What was previously seen as awkward and sometimes even embarrasing is now embraced with great pride. Sustainability has become a higher priority in the industry and this changes their expectations of business partners.

Olivia Rothschild at Hyber claimed she had seen an increasing interest among the big producers in offering leasing through a third party. The reason, Rothschild argues, is the combination of sustainable consumption and the ability to increase their profit margin. Garments of high quality and long sustainability have strong second-hand value, which benefits the second-hand market in comparison to factory new clothes. By leasing the same garment to several costumers, it is therefore possible to offer high quality clothes without the profit margin dropping.

\section{DISCUSSION}

Our interviewees started their business in anger over the climate crisis and with a strong desire to contribute to a more environment-friendly world. They had previously been involved in nonprofit organizations but experienced frustration at not being able to fund their work. Hence they began to look to social entrepeneurship as a way to both contributing to society and protecting the environment while also being commercially profitable. If we return to our starting-point, this is a micro-level attempt to bridge the gap between the UN goals and the paradox set by the CSR pyramid - although our social entrepreneurs were barely aware of this. 'Performance' may in this perspective be understood as the extent to which the social entrepreneur is an agent of change (cf. Dees, 1998; Partzsch \& Ziegler, 2011) and a provocateur (cf. Johannisson and Wigren, 2009) who contributes to the transformation of society. Profitability is expressed as a means to increase the transformational power of the company, especially in a long-run aim of creating social value, rather than merely making short-term profits (cf. Dees 1998).

Money is just a means to expand and thereby reach out to more people, which at the end of the day leads to a greater lowering of waste (Daniel Gillan at Food Fighters).

Jenny Ekman at Sajkla had a slighty different angle. A growing economy was not just beneficial for the firm, but a prime mover for transformation; her point being that a fundamental rethinking of market logics is necessary. Given that there is room for profits in circular business models, the goods such firms can bring to the market will stay as long as they can sell profitably to a lower price than the customers would have to pay for newly produced products. The rethinking of the market logics, Ekman claimed, is that reuse and recycling must be superior to profitability, although profitability is still necessary and will never cease to exist. This train of thought was obvious to several of our intervewees.

Accordingly, there is little doubt that social entrepeneurship might be advantageous from several points of view in meeting the need for more sustainable consumption patterns. Social 
entrepreneurship opens new ways to prioritize sustainability over profitability without depending on support from donors or governments; it is self-funding. There is also a possible spill-over effect: small companies might influence bigger firms to employ similar business models; remember the Emerging Davids vs. the Greening Goliaths.

Returning to the parallel with Schumpeter, his understanding of creative destruction was a constant and evolutionary process, not necessarily slow, but stretching over a fairly long period of time; he strongly emphasized the complexity of the process and that it could only be analyzed from an overall perspective (Schumpeter, 2003 [1942]). We believe our findings are possible to unify with Schumpeter's standpoint. Listening to our informants' stories about their businesses, there is no doubt a connection between what they wish to achieve and 'creative destruction.' One example is Daniel Gillan at Food Fighters who expressed it in the following words:

It is not about excluding companies, it is just a great transformation; we must remove the bad firms in favor of the good ones.

Also Jonas Ingre at Goodlist speaks of a development where environmentally worse alternatives are replaced by better ones, in Goodlist's case by visualizing companies' performance:

This is our goal, our view of Goodlist's contribution. People shall be able to find products and services that contribute to something good. Not primarily that they drop somewhat decent alternatives, but that they chose even better ones, thereby pressing for the development of the rejected firms' goods and services.

Since both Food Fighters and Goodlist have developed platforms based on rankings between producers and retailers, it opens for the continuous drive that Schumpeter (2003 [1942]) argued characterizes economic transformation and innovations. In other words, social entrepreneurs facilitate creative destruction. Ingre at Goodlist stresses that the company's digital solutions not only have downward price pressure through its comparisons, but also may make firms compete to be top ranked regarding sustainability.

Even more striking though, is the view of our social entrepreneurs and established market actors as Emerging Davids and Greening Goliaths. Hyber's cooperation with established garment producers is in this perspective an extention of the latters' traditional sales. The contribution is price-reducing, which makes the 'good' clothes available to more groups in society. The co-evolution furthermore shows a development toward alternative consumption patterns where the temporary access to a product might in itself be just as valuable as ownership. Hyber's co-evolution with garment producers makes business models possible that motivate production of sustainable clothes since this leads to more rentals. Hyber, Food Fighters and the other social entrepreneurs accordingly take the role of the agent who in the words of Partzsch och Ziegler (2011) has the ability to look beyond 'normative attitudes' in society and find room for a change of established societal structures. The outcome can be understood as a contemporary version of creative destruction where the economy at large is transformed due to the cooperation between small social entrepreneurs and big established corporations.

According to Young et al. (2010) the number of sustainable consumption choices increases depending on the number of sustainable products available, not on some minor sustainable products that are often difficult for the consumer to find. The fact that retailers employ Rekokollen's platform in order to include more sustainable alternatives in their selections is therefore contributing more to sustainability than if the sustainable supply is limited to a few, although good, alternatives. A low-ranked firm at Goodlist can compare itself with and adapt to higher ranked competitors in a 
similar way as those who look to Food Fighters's ranking of food-chains. If we return to Banerjee's (2003) conclusion that a 'greener' supply does not necessarily contribute to ecological sustainability in terms of a more sustainable consumption pattern, we can once again listen to the words of Jonas Ingre at Goodlist that highlights another aspect of the creative destruction facilitated by Goodlist's platforms:

The consumption pattern at large must be changed. We do not just need to buy more sustainable products, a replacement is not enough but we must also shop less.

The platforms thus make possible a way to reward more sustainable companies at the cost of others without even consuming. This promotes a decrease in consumption in general at the same time as the conditions increase for a consumption that is actually made in the most sustainable way. 


\section{CONCLUSION}

So, is social entrepreneurship, here illustrated by some small companies in the Swedish context, able to bridge the gap between the UN's global goals and the need for profit in ordinary firms? Sadly the answer must be no: the gap is too big for such a small movement to bridge by itself. Yet, that was not what we expected when we started this study. Big companies especially in the petroleum industry are extremely powerful. There is a strong need for political transnational solutions here, which obviously goes beyond the scope of our article.

We have studied social entrepeneurs in highly polluting and water consuming and wasteful sectors such as the garment and food industries and find that social entrepreneurship can make a major impact. Time is running out for solving the climate crisis and the impact of Emerging Davids on Greening Goliaths may not keep pace with dangerous climate change. Still Emerging Davids on Greening Goliaths are worth considering. They represent a grass-root movement that might trigger other grass-root movements, consumer movements, and also big corportions. They should therefore not be neglected; their influence might very well make a great contribution to transnational political attempts to solve the global climate crisis. Maybe the old slogan think globally, act locally is not too bad after all.

\section{Acknowldegements}

Our warm thanks to Lina Daly, Professor Peter A. Swenson, Yale University, and anonymous reviewers for useful comments on previous drafts. 


\section{REFERENCES}

Austin, J., Stevenson, H., \& Wei-Skillern, J. (2006). Social and commercial entrepreneurship: Same, different, or both? Entrepreneurship theory and practice, 30(1), 1-22.

Banerjee, S. B. (2003). Who sustains whose development? Sustainable development and the reinvention of nature. Organization studies, 24(1), 143-180.

Bornstein, D. and Davis, S. (2010). Social Entrepreneurship: What Everyone Needs to Know. Oxford: Oxford University Press.

Carroll, A. B. (1991). The pyramid of corporate social responsibility: Toward the moral management of organizational stakeholders. Business horizons, 34(4), 39-48.

Carroll, A. B. (2016). Carroll's pyramid of CSR: taking another look. International Journal of Corporate Social Responsibility, 1(3).

Dees, J. G. (1998). The Meaning of "Social Entrepreneurship". http://e145.stanford.edu/upload/articles/dees_SE.pdf

Dees, J. G. (2007). Taking social entrepreneurship seriously. Society New Brunswick, 44(3), 24.

Dunlap, R. E. (2013). Climate Change Skepticism and Denial: An Introduction. American Behavioral Scientist, 57(6), 691-698.

Hockerts, K., and Wüstenhagen, R. (2010). Greening Goliaths versus emerging Davids - Theorizing about the role of incumbents and new entrants in sustainable entrepreneurship. Journal of business venturing, 25(5), 481-492.

Jackson, T. (2011). Societal transformations for a sustainable economy. Natural Resources Forum, $35(3)$.

Johannisson, B., \& Wigren, C. (2009). Samhällsentreprenören som provokatör. In M. Gawell, B. Johannisson and M. Lundqvist (eds.) Samhällsentreprenörer: En forskarantologi om samhällsentreprenörskap. Stockholm: KK-stiftelsen.

Lorek, S. and Spangenberg, J. H. (2014). Sustainable consumption within a sustainable economy Beyond green growth and green economies. Journal of Cleaner Production, 63, 33-44.

McCracken. G. (1988). The Long Interview. Newbury Park, CA: Sage.

Mitcham, C. (1995). The concept of sustainable development: its origins and ambivalence. Technology in society, 17(3), 311-326.

Nguyen, H. V., Nguyen, C. H., \& Hoang, T. T. B. (2019). Green consumption: Closing the intentionbehavior gap. Sustainable Development, 27(1), 118-129.

Partzsch, L., and Ziegler, R. (2011). Social entrepreneurs as change agents: A case study on power and authority in the water sector. International Environmental Agreements, 11(1), 63-83.

Purvis, B., Mao, Y., and Robinson, D. (2019). Three pillars of sustainability: in search of conceptual origins. Sustainability science, 14(3), 681-695.

Rahdari, A., Sepasi, S., \& Moradi, M. (2016). Achieving sustainability through Schumpeterian social entrepreneurship: The role of social enterprises. Journal of Cleaner Production, 137, 347-360.

Rosling, H. (2018). Factfulness: Ten reasons we're wrong about the world - and why things are better than you think. London: Sceptre.

Schumpeter, J.A. (1983 [1934]). The theory of economic development: an inquiry into profits, capital, credit, interest, and the business cycle. New Brunswick: Transaction Publishers.

Schumpeter, J. A. (2003 [1942]). Capitalism, socialism and democracy. George Allen \& Unwin. http://digamo.free.fr/capisoc.pdf.

Thörnqvist, C. and Bernhardsson, S. (2015). Their own stories - How Polish construction workers posted to Sweden experience their job situation, or resistance versus life projects. Transfer, 21(1), 23-36.

United Nations (2016), Entrepreneurship for sustainable development. Resolution adapted by the General Assembly.

WCED (World Commission on Environment and Development) (1987), Our Common Future. Oxford/New York: Oxford University Press.

Young, W., Hwang, K., McDonald, S., and Oates, C. J. (2010). Sustainable consumption: green consumer behaviour when purchasing products. Sustainable development, 18(1), 20-31. 